\title{
Integrasi Nilai Keislaman dan Kemampuan Komunikasi Matematis Pada Buku Ajar Program Linier (Sebuah Studi Pengembangan)
}

\author{
Hayatun Nufus ${ }^{1 *}$, Erdawati Nurdin², Rezi Ariawan ${ }^{3}$ \\ ${ }^{1,2}$ Universitas Islam Negeri Sultan Syarif Kasim Riau, Pekanbaru, Riau, 28293, Indonesia \\ ${ }^{3}$ Universitas Islam Riau, Pekanbaru, Riau, 28284, Indonesia
}

Pengiriman: 30/September/2020; Diterima: 25/Maret/2021; Publikasi: 31/Maret/2021

DOI: https://doi.org/10.31629/jg.v6i1.2556

\begin{abstract}
Abstrak
Keberadaan nilai-nilai Islam dan kemampuan matematis dalam pembelajaran sangat penting untuk diajarkan dan dimiliki oleh peserta didik. Oleh sebab itu, salah satu cara untuk dapat menanamkan nilai Islam dan kemampuan matematis tersebut adalah dengan mengintegrasikannya dalam buku ajar. Penelitian ini bertujuan untuk menghasilkan buku ajar program linier yang valid dan praktis dengan mengintegrasikan nilai keislaman dan kemampuan komunikasi matematis merupakan tujuan dilakukannya penelitian ini. Jenis penelitian yang digunakan adalah penelitian pengembangan dengan desain ADDIE. Data dikumpulkan dengan teknik angket menggunakan instrumen lembar angket validasi buku ajar dan angket praktikalitas. Data dianalisis dengan menggunakan deskriptif kuantitatif berupa rata-rata persentase. Hasil penelitian menunjukkan bahwa: (1) buku ajar yang dikembangkan berada pada tingkat validitas sangat valid dengan numerik nilai validitas sebesar 92,5\%, (2) buku ajar yang dikembangkan berada pada tingkat praktikalitas sangat praktis, dengan numerik nilai praktikalitas sebesar $85,5 \%$.
\end{abstract}

Kata kunci: buku ajar; program linier; terintegrasi keislaman; dan komunikasi matematis

\begin{abstract}
The existence of islamic values and mathematical abilities in learning is very important to be taught and possessed by students. Therefore, one way to be able to instill islamic values and mathematical abilities is to integrate them in textbooks. This study aims to produce a valid and practical linear program textbook by integrating Islamic values and mathematical communication ability is the aim of this research. The type of research used is research and development using ADDIE design. Data were collected using a questionnaire technique using the validation sheet questionnaire for the textbook and practicality questionnaire sheet. Data were analyzed using quantitative descriptive in the form of average percentages. The results showed that: (1) the textbook developed was at a very valid validity level with a numerical validity value of $92.5 \%$, (2) the textbook developed was at a very practical level of practicality, with a practicality numerical value of $85.5 \%$.
\end{abstract}

Keywords: text book; linier program; islamic integrated; communication ability

*Penulis Korespondensi

Email Address: hayatun.nufus@uin-suska.ac.id

Handphone : +62 85278359593 


\section{JURNAL GANTANG. Maret 2021; VI(1): 47 - 60 \\ p-ISSN. 2503-0671 \\ e-ISSN. 2548-5547}

\section{Pendahuluan}

Pendidikan merupakan salah satu sarana dalam mencerdaskan kehidupan bangsa. Dalam proses pendidikan, pembentukan kognitif, afektif dan psikomotorik selalu menjadi hal yang paling di kedepankan. Padahal selain aspek di atas terdapat aspek lain yang harus dikembangkan sebagai hasil dari proses pendidikan itu sendiri, diantaranya menjadikan manusia yang beradab dan bertanggung jawab. Hal ini sejalan dengan tujuan Pendidikan Nasional yang termuat dalam UU RI Nomor 20 Tahun 2003 tentang Sistem Pendidikan Nasional, yaitu untuk mewujudkan manusia Indonesia yang memiliki kekuatan spiritual keagamaan, pengendalian diri, kepribadian, kecerdasan, akhlak mulia, serta keterampilan yang diperlukan masyarakat, bangsa dan Negara (Menteri Pendidikan Nasional, 2003).

Untuk dapat mewujudkan tujuan tersebut, salah satu cara yang dapat dilakukan adalah dengan mengintegrasikan nilai-nilai keislaman dalam pembelajaran, terutama pembelajaran matematika. Fitriyani \& Kania (2019) menyatakan bahwa pembentukan karakter bangsa dapat dilakukan dengan cara mengintegrasikan nilai-nilai keislaman dengan konsep matematika. Selanjutnya Supriadi (2015) nilai keislaman bisa diintegrasikan dalam pembelajaran dalam bentuk contoh soal, soal latihan ataupun soal ujian dalam perspektif islam

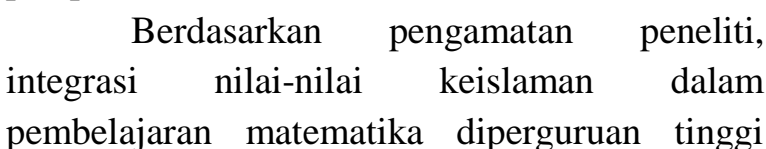
masih belum dilakukan, hal ini dapat dilihat dari banyaknya buku ajar yang telah disusun masih bersifat umum. Hal ini sejalan dengan observasi yang dilakukan oleh Kurniati (2015) yaitu integrasi ilmu keislaman dalam pembelajaran matematika belum optimal dilakukan. Integrasi keislaman hanya sebatas dilakukan pada pemisahan tempat duduk dan membaca Al-Quran sebelum memulia pembelajaran. Padahal masih menurut Kurniati (2015) integrasi ilmu keislaman dalam pembelajaran merupakan ciri khas dalam lembaga pendidikan Islam.
Berdasarkan hal tersebut, secara tidak langsung mengintegrasikan nilai keislaman dalam pembelajaran harus dilakukan, yaitu dengan mengintegrasikan nilai keislaman tersebut ke dalam buku ajar. Menurut Khikmiyah \& Midjan (2017) buku ajar adalah bahan-bahan pelajaran yang disusun secara sistematis yang dapat digunakan untuk memotivasi siswa untuk belajar, mengatasi kesulitan belajar siswa. Selanjutnya Febrianto \& Puspitaningsih (2020) menyatakan bahwa penentu keberhasilan belajar adalah tersedianya sumber belajar atau media pembelajaran yang mudah digunakan oleh mahasiswa. Oleh sebab itu, dalam penelitian ini, peneliti mencoba untuk mengembangkan buku ajar dengan mengintegrasikan nilai keislaman di dalamnya.

Selain nilai keislaman yang dintegrasikan dalam buku ajar tersebut, terdapat aspek penting lainnya yang harus dimuatkan dalam buku ajar, yaitu kemampuan komunikasi matematis. Kemampuan komunikasi matematis merupakan kemampuan yang penting bagi siswa (Nartani, Hidayat, \& Sumiyati, 2015). Selanjutnya menurut Hodiyanto (2017) aspek yang perlu diajarkan kepada peserta didik adalah kemampuan dalam mengungkapkan pemikirannya baik secara lisan maupun tulisan. Keterampilan komunikasi yang dimiliki oleh siswa sekarang akan berguna bagi mereka di masa akan datang (Wichelt \& Kearney, 2009). Prestasi belajar matematika siswa dapat dipengaruhi oleh kemampuan komunikasi matematis (Astuti \& Leonard, 2015).

Berdasarkan hasil ujian akhir semester yang telah dilakukan di akhir pembelajaran pada mata kuliah Program Linier, diperoleh informasi bahwa kemampuan komunikasi matematis mahasiswa tergolong masih rendah. Soal-soal yang digunakan pada ujian akhir semester tersebut terkait dengan indikator kemampuan komunikasi matematis, seperti menyatakan persitiwa sehari-hari ke dalam bentuk model matematis dan menyelesaikannya, menjelaskan ide dan situasi secara tertulis menggunakan gambar, grafik, atau secara aljabar, serta membaca representasi matematika tertulis dengan 
pemahaman. Adapun data tersebut dapat dilihat pada tabel 1 di bawah ini.

Tabel 1.

Deskriptif kuantitatif kemampuan komunikasi matematis mahasiswa

\begin{tabular}{cccccc}
\hline & $\begin{array}{c}\text { T.A. } \\
\text { 2018/201 } \\
\mathbf{9}\end{array}$ & \multicolumn{2}{c}{$\begin{array}{c}\text { T.A. } \\
\text { 2017/2018 }\end{array}$} & \multicolumn{2}{c}{$\begin{array}{c}\text { T.A. } \\
\text { 2016/2017 }\end{array}$} \\
\cline { 2 - 5 } & Kelas B & $\begin{array}{c}\text { Kela } \\
\text { s B }\end{array}$ & $\begin{array}{c}\text { Kela } \\
\text { s C }\end{array}$ & $\begin{array}{c}\text { Kela } \\
\text { S B }\end{array}$ & $\begin{array}{c}\text { Kela } \\
\text { s C }\end{array}$ \\
\hline $\begin{array}{c}\text { Rata } \\
\text {-rata }\end{array}$ & 84,03 & 82,47 & 78,54 & 81,85 & 45 \\
\hline $\begin{array}{c}\text { Mak } \\
\text {. }\end{array}$ & 100 & 100 & 99 & 100 & 100 \\
\hline Min. & 40 & 25 & 35 & 25 & 10 \\
\hline
\end{tabular}

Berdasarkan informasi yang disajikan pada tabel di atas, peningkatan kemampuan komunikasi matematis mutlak harus dilakukan. Salah satu caranya adalah dengan mengintegrasikannya ke dalam buku ajar.

Berdasarkan uraian di atas, maka penelitian ini bertujuan untuk menghasilkan sebuah buku ajar program linier terintegrasi keislaman berbasis kemampuan komunikasi matematis. Buku ajar yang dihasilkan diharapkan berada pada tingkat validitas kategori valid dan tingkat praktikalitas kategori praktis.

\section{Metode Penelitian}

Penelitian ini merupakan penelitian pengembangan dengan desain penelitian menggunakan desain ADDIE (Analysis, Design, Development, Implementation, dan Evaluation). Model ADDIE dapat digunakan untuk mengembangkan bahan ajar menulis serta mampu mengembangkan bahan ajar sesuai dengan kebutuhan penulis (Asmayanti, Cahyani, \& Idris, 2020). Menurut Brook et al (Mahardhika, 2015) model ADDIE digunakan dengan tujuan pengembangan landasan teoritis desain pembelajaran.

Tahapan dalam penelitian ini dengan menggunakan desain ADDIE dapat dilihat pada Tabel 2. Penelitian ini dilaksanakan di Jurusan Pendidikan Matematika Fakultas Tarbiyah dan Keguruan UIN Suska Riau dengan subjek penelitian adalah mahasiswa semester 5 tahun ajaran 2019/2020. Pemilihan subjek penelitian dilakukan secara purposive sampling dengan mempertimbangkan kemampuan akademis mahasiswa dan jenis kelamin yang heterogen. Dengan pertimbangan tersebut, maka yang terpilih sebagai subjek penelitian adalah seluruh mahasiswa kelas 5B.

Tabel 2.

Tahapan kegiatan ADDIE pada penelitian

\begin{tabular}{l}
\hline \multicolumn{1}{c}{ Aktivitas } \\
\hline \hline Tahap Analysis \\
Pra perencanaan: pemikiran tentang buku ajar baru \\
yang akan dikembangkan. \\
Mengidentifikasi buku ajar yang sesuai dengan \\
kondisi mahasiswa, tujuan belajar, mengidentifikasi \\
isi/materi pembelajaran, mengidentifikasi \\
lingkungan belajar dan strategi penyampaian dalam \\
pembelajaran.
\end{tabular}

Tahap Design

Merancang konsep buku ajar di atas kertas.

Merancang perangkat pengembangan terkait buku ajar. Rancangan ditulis untuk masing-masing sub bab buku ajar.

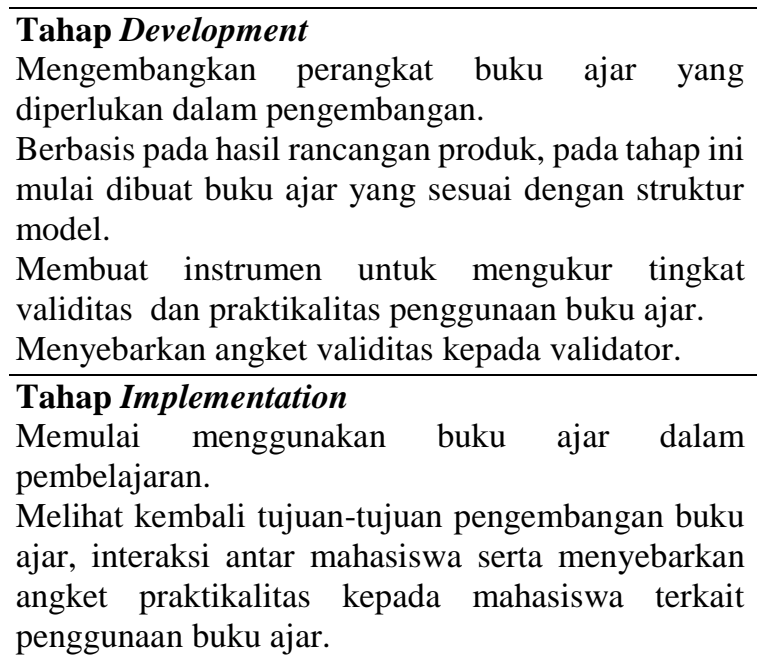

\section{Tahap Evaluation}

Melihat kembali dampak pembelajaran dengan cara yang kritis.

Mengukur ketercapaian tujuan pengembangan buku ajar.

Mengukur apa yang telah mampu dicapai akibat penggunaan buku ajar.

Data penelitian dikumpulkan dengan teknik non-tes menggunakan angket untuk memperoleh data terkait validitas dan praktikalitas buku ajar yang dikembangkan. 


\section{JURNAL GANTANG. Maret 2021; VI(1): 47 - 60 \\ p-ISSN. 2503-0671 \\ e-ISSN. 2548-5547}

Intrumen penelitian yang digunakan untuk mengumpulkan data dalam penelitian ini terdiri dari lembar angket validasi ahli terhadap buku ajar. Lembar validasi ini disusun dengan menggunakan beberapa aspek, diantaranya: (1) Aspek kelayakan penyajian, dengan indikator: sistematika penyajian dan keruntutan konsep; (2) Aspek kelayakan isi, dengan indikator: kelengkapan materi, keluasan materi, kedalaman materi, dan keakurasian materi; (3) Aspek kesesuaian dengan prinsip integrasi keislaman dan kemampuan komunikasi matematis, dengan indikator: kesesuaian dengan prinsip integrasi keislaman dan kesesuaian dengan indikator kemampuan komunikasi matematis; dan (4) Aspek kelayakan bahasa, dengan indikator: ketepatan penggunaan kaidah bahasa dan kemampuan memotivasi dan menyampaikan pesan.

Setiap indikator terwakilkan oleh serangkaian pilihan pernyataan (dengan skor 1 sampai dengan 4, sesuai dengan kondisi masingmasing skor penilaian). Sehingga, jumlah rangkaian item pernyataan adalah sebanyak sepuluh rangkaian pilihan pernyataan.

Selanjutnya adalah lembar angket praktikalitas buku ajar. Lembar ini disusun dengan menggunakan enam variabel praktikalitas. Pertama, minat mahasiswa dan tampilan buku, dengan indikator: (1) kesesuaian tampilan buku dalam menarik minat mahasiswa ketika menggunakannya (terdiri atas enam pernyataan) dan (2) ketertarikan mahasiswa terhadap pembelajaran dan mata kuliah program linier dengan menggunakan buku ajar (terdiri dari 3 pernyataan). Kedua, proses penggunaan, dengan indikator: (1) kepraktisan buku ajar yang disesuaikan dengan kondisi belajar mahasiswa (terdiri dari 4 pernyataan) dan (2) penggunaan buku ajar dalam meningkatkan aktivitas belajar mahasiswa (terdiri atas 2 pernyataan).

Ketiga, kemampuan komunikasi matematis dan materi, dengan indikator: (1) kesesuaian materi, contoh soal, dan soal latihan pada buku ajar dalam memfasilitasi kemampuan mahasiswa untuk menjelaskan ide, situasi, dan relasi matematika secara tertulis dengan menggunakan gambar, grafik, maupun secara aljabar (terdiri atas 1 pernyataan), (2) kesesuaian materi, contoh soal, dan soal latihan pada buku ajar dalam memfasilitasi kemampuan mahasiswa untuk membaca representasi matematika tertulis dengan pemahaman dan menuliskannya (terdiri atas 1 pernyataan), (3) kesesuaian materi, contoh soal, dan soal latihan pada buku ajar dalam memfasilitasi kemampuan mahasiswa untuk menyatakan peristiwa sehari-hari ke dalam model matematis dan menyelesaikannya (terdiri atas 1 pernyataan).

Keempat, waktu, dengan indikator: keselarasan antara sistematika materi pada buku ajar dengan alokasi waktu di perguruan tinggi (terdiri atas 2 pernyataan). Kelima, evaluasi, dengan indikator: keterdukungan latihan soal pada buku ajar dalam membantu mahasiswa untuk mengevaluasi pemahamannya terkait materi pembelajaran (terdiri atas 2 indikator). Keenam, pemahaman keislaman dan materi, dengan indikator: (1) kemenarikan penyajian aspek keislaman pada buku ajar dalam meningkatkan pemahaman keislaman mahasiswa (terdiri atas 2 pernyataan), dan (2) kemenarikan penyajian aspek keislaman pada buku ajar dalam meningkatkan pemahaman keislaman mahasiswa (terdiri atas 1 pernyataan).

Teknik analisis data pada penelitian ini menggunakan deskriptif kuantitatif berupa ratarata persentase. Pertama, analisis data hasil uji validitas dilakukan dengan tahapan sebagai berikut: (a) menjumlahkan nilai tiap indikator lembar validasi. Skala penilaian lembar validasi berdasarkan Skala Likert (tanpa poin netral) yang disajikan pada Tabel 3.

Tabel 3.

Kategori penilaian lembar validasi

\begin{tabular}{cc}
\hline Kategori & Skor \\
\hline Sangat Tidak Baik & 1 \\
\hline Tidak Baik & 2 \\
\hline Baik & 3 \\
\hline Sangat Baik & 4 \\
\hline
\end{tabular}

(b) mencari nilai nilai rata-rata tiap indikator yang diberikan validator dengan rumus sebagai berikut: 


$$
\mathrm{Va}=\frac{T S e}{T S h} \times 100 \% \ldots \text { Akbar (2013) }
$$
maka:

Karena validator terdiri atas 2 orang,

$$
\begin{aligned}
& V_{1}=\frac{T S e}{T S \square} \times 100 \% \\
& V_{2}=\frac{T S e}{T S \square} \times 100 \%
\end{aligned}
$$

(c) menentukan validasi gabungan dengan rumus sebagai berikut:

$$
V=\frac{V_{1}+V_{2}}{2}=\cdots \%
$$

Keterangan:

$$
\begin{gathered}
V=\text { Validitas gabungan } \\
V_{1}=\text { Validitas dari ahli }-1 \\
V_{2}=\text { Validitas dari ahli }-2 \\
T S h=\text { Total skor maksimal yang diharapkan } \\
T S e=\text { Total skor empiris (hasil validasi dari } \\
\quad \text { validator) }
\end{gathered}
$$

\begin{tabular}{|c|c|c|}
\hline Nilai Rata-rata & Kategori & Keterangan \\
\hline $81 \% \leq V \leq 100 \%$ & $\begin{array}{c}\text { Sangat } \\
\text { Valid }\end{array}$ & $\begin{array}{l}\text { Buku ajar dapat } \\
\text { digunakan tanpa } \\
\text { revisi }\end{array}$ \\
\hline $61 \% \leq V<81 \%$ & Valid & $\begin{array}{l}\text { Buku ajar dapat } \\
\text { digunakan } \\
\text { namun perlu } \\
\text { dilakukan revisi } \\
\text { kecil }\end{array}$ \\
\hline $41 \% \leq V<61 \%$ & $\begin{array}{l}\text { Cukup } \\
\text { Valid }\end{array}$ & $\begin{array}{l}\text { Buku ajar dapat } \\
\text { digunakan } \\
\text { namun perlu } \\
\text { dilakukan revisi } \\
\text { sedang }\end{array}$ \\
\hline $21 \% \leq V<41 \%$ & $\begin{array}{l}\text { Tidak } \\
\text { Valid }\end{array}$ & $\begin{array}{l}\text { Buku ajar } \\
\text { disarankan } \\
\text { untuk tidak } \\
\text { digunakan } \\
\text { karena perlu } \\
\text { dilakukan revisi } \\
\text { besar }\end{array}$ \\
\hline $0 \% \leq V<21 \%$ & $\begin{array}{c}\text { Sangat } \\
\text { Tidak } \\
\text { Valid }\end{array}$ & $\begin{array}{l}\text { Buku ajar tidak } \\
\text { bisa digunakan }\end{array}$ \\
\hline
\end{tabular}

(d) menentukan kategori nilai rata-rata berdasarkan skala likert dan menentukan kategori validasi buku ajar, dengan kriteria seperti disajikan pada Tabel 4.

Tabel 4.

Kategori validasi buku ajar

Sumber: Modifikasi Riduwan \& Sunarto (2013)

Kedua, analisis data hasil angket praktikalitas. Analisis praktikalitas buku ajar dihitung dengan mencari persentase praktikalitas buku ajar. Menurut Sudijono (2008), persentase dari suatu nilai dapat dihitung dengan menggunakan rumus sebagai berikut:

$$
P=\frac{f}{N} \times 100 \%
$$

Keterangan:

$P$ : Persentase penilaian

$f:$ Skor yang diperoleh

$N$ : Total Skor

Tabel 5.

Kriteria praktikalitas buku ajar

\begin{tabular}{ccl}
\hline Nilai Persentase & Kategori & \multicolumn{1}{c}{ Keterangan } \\
\hline $81 \%<P \leq 100 \%$ & $\begin{array}{l}\text { Sangat } \\
\text { Praktis }\end{array}$ & $\begin{array}{l}\text { Buku ajar dapat } \\
\text { digunakan tanpa } \\
\text { revisi }\end{array}$ \\
\hline $61 \%<P \leq 81 \%$ & Praktis & $\begin{array}{l}\text { Buku ajar dapat } \\
\text { digunakan namun } \\
\text { perlu dilakukan } \\
\text { revisi kecil }\end{array}$ \\
\hline $41 \%<P \leq 61 \%$ & Cukup & $\begin{array}{l}\text { Buku ajar dapat } \\
\text { digunakan namun } \\
\text { perlu dilakukan } \\
\text { revisi sedang }\end{array}$ \\
\hline & Praktis & $\begin{array}{l}\text { Buku ajar } \\
\text { disarankan untuk } \\
\text { tidak digunakan } \\
\text { karena perlu } \\
\text { dilakukan revisi } \\
\text { besar }\end{array}$ \\
\hline $21 \%<P \leq 41 \%$ & Kurang \\
& Praktis & $\begin{array}{l}\text { Buku ajar tidak } \\
\text { bisa digunakan }\end{array}$ \\
\hline
\end{tabular}

Sumber: Modifikasi Riduwan (2010)

\section{Hasil dan Pembahasan \\ Hasil Penelitian}

Sesuai dengan prosedur penelitian yang disusun berdasarkan tahapan penelitian pengembangan dengan desain ADDIE, maka hasil penelitian yang dimaksud dalam penelitian ini diperoleh melalui kegiatan yang telah dilakukan dengan berpedoman pada prosedur tersebut.

\section{Tahap Analysis}

Pada tahapan ini, peneliti melakukan dua kegiatan yaitu analisis kurikulum dan analisis kebutuhan. Hal yang peneliti lakukan dalam kegiatan analisis kurikulum ini yaitu: (1) Menentukan apa saja materi prasyarat yang harus 


\section{JURNAL GANTANG. Maret 2021; VI(1): 47 - 60 \\ p-ISSN. 2503-0671 \\ e-ISSN. 2548-5547}

dipenuhi oleh mahasiswa.Berpedoman pada inti materi pada mata kuliah program linier, maka materi prasyarat yang harus dipenuhi oleh mahasiswa yaitu: materi persamaan linier satu variabel, pertidaksamaan linier satu variabel, persamaan linier dua variabel, sistem persamaan linier dua variabel, pertidaksamaan linier dua variabel, dan sistem pertidaksamaan linier dua variabel. (2) Menentukan apa saja bab (sub materi) yang akan dipelajari mahasiswa. Dengan mempertimbangkan berbagai kondisi seperti ketersediaan waktu, sumber daya manusia, dan dana, maka hanya lima bab materi saja yang dikembangkan pada buku ajar, yaitu: (a) konsep dasar program linier; (b) metode grafik; (c) metode aljabar; (d) metode sudut; dan (e) metode simpleks. (3) Menentukan tujuan pembelajaran yang harus dipenuhi oleh mahasiswa.

Selama ini, peneliti sendiri selalu terlibat dalam mengampu mata kuliah program linier, sejak tahun ajaran 2016/2017 hingga tahun ajaran 2018/2019. Artinya, sudah tiga tahun berturutturut peneliti terlibat dalam mata kuliah program linier. Waktu yang cukup untuk melihat kekurangan dan menganalisis kebutuhan terkait buku ajar.

Selama menjalani proses perkuliahan, kegiatan pembelajaran menggunakan buku ajar yang peneliti sendiri sebagai penulis bersama seorang rekan sejawat lainnya. Buku ajar tersebut masih bersifat umum, belum memuat nilai-nilai keislaman, padahal buku beredar di perguruan tinggi keislaman. Selain itu, soal-soal dalam buku ajar juga belum memuat indikator kemampuan berpikir tingkat tinggi, salah satunya kemampuan komunikasi matematis, padahal berdasarkan hasil ujian tengah semester (memuat lima bab materi yang dikembangkan), nilai yang diperoleh mahasiswa belum maksimal, sebagaimana dapat dilihat pada tabel 1 di atas.

Selanjutnya, selama menggunakan buku ajar, peneliti memiliki beberapa catatan, diantaranya bahwa langkah-langkah yang tertulis pada setiap metode belum terlalu rinci, sehingga dalam menggunakan buku ajar tersebut peneliti perlu menambahkan beberapa rincian untuk memperjelas penerapan langkah-langkah penggunaan metode. Berdasarkan uraian tersebut, maka kebutuhan akan nilai-nilai keislaman, kebutuhan akan soal yang memuat indikator kemampuan komunikasi matematis, dan kebutuhan akan rincian langkah-langkah penerapan tiap metode perlu diperhatikan dalam pengembangan buku ajar ini.

\section{Tahap Design}

Pada tahap ini, peneliti merancang draft buku ajar yang memuat cover, judul bab, tujuan pembelajaran, konsep materi, judul sub bab, sajian materi, contoh soal, rangkuman, dan latihan-latihan, serta sekaligus merancang instrumen yang dibutuhkan ketika mengembangkan buku ajar. Nilai - nilai keislaman yang diintegrasika ke dalam buku ajar ini di desain untuk pemberian motivasi dan penyajian permasalahan. Berikut akan disajikan contoh desainnya.

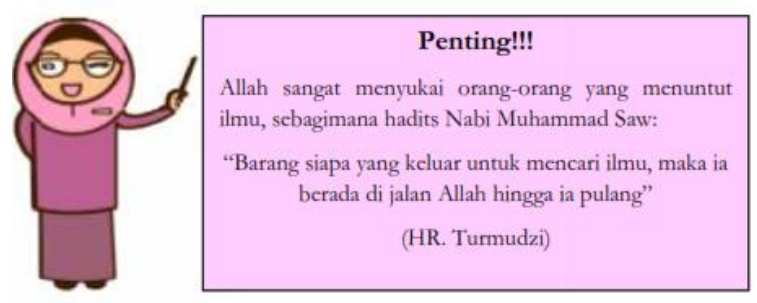

Gambar 1. Integrasi nilai keislaman dalam buku ajar program linier pada bagian pendahuluan sebagai motivasi Shalat

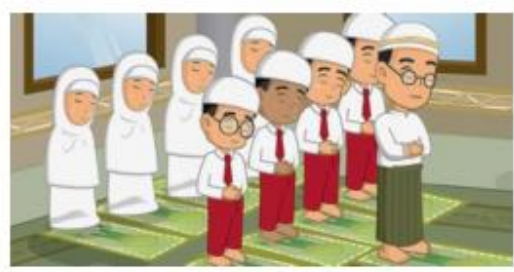

Gambar 1.2. Kegiatan Shalat Berjama'ah

Shalat adalah penghubung antara Allah dan hamba-Nya. Karena itu, shalat merupakan ketenangan dan kebahagiaan bagi orang yang bertaqwa, scbagaimana hadits Nabi Muhammad Saw:

"Dijadikan ketenanganku, di dalam shalat. Dan apabila mendapatkan satu kesulitan berkata kepada Bilal: Wahai Bilal, qamatlah (untuk shalat)! agar dengan shalat tersebut kami tenang" (HR. Abu Dawud)

Sctiap shalat memiliki jumlah raka'at yang berbeda-beda.

a. Dalam sehari, setiap muslim waiph melakukan shalat fardhu dengan jumlah raka'at tepat 17 raka'at. Bagaimanakah bentuk model matematisnya?

Gambar 2a. Integrasi nilai keislaman dalam buku ajar program linier pada bagian penyajian permasalahan 
b. Dalam sehari, setiap muslim dianjurkan untuk melakukan shalat sunnah rawatib dengan total raka'at untuk semuanya adalah maksimal sebanyak 12 raka'at, sebagaimana hadits Nabi Muhammad Saw:

"Barangsiapa yang tidak meninggalkan dua belas (12) raka'at pada shalat sunnah rawatib, maka Allah akan bangunkan baginya rumah di syurga, (yaitu): empat raka'at sebelum zuhur dan dua raka'at sesudahnya, dan dua raka'at sesudah maghrib, dan dua raka'at sesudah isya, dan dua raka'at sebelum subuh: (HR. At-Tarmidzi).

Bagaimanakah bentuk model matematis terkait jumlah raka'at seluruh shalat sunnah rawatib?

Gambar 2b. Integrasi nilai keislaman dalam buku ajar program linier pada bagian penyajian permasalahan

Selanjutnya kemampuan komunikasi dalam buku ajar ini di desain dengan memunculkannya dalam bentuk pertanyaan dari permasalahan yang disajikan. Berikut akan disajikan contoh desainnya.

a. Buatlah model matematis dari permasalahan di atas (fungsi kendala dan fungsi tujuan).

b. Gambarkanlah grafik yang terbentuk dari seluruh fungsi kendala dan syarat ikatan non negatif dari permasalahan di atas.

c. Berapakah harta pembagian yang diperoleh pasukan kaum Muslimin yang ikut berjuang?

Gambar 3. Integrasi kemampuan komunikasi matematis dalam buku ajar program linier pada bagian pertanyaan dari permasalahan

\section{Tahap Development}

Pada tahapan ini melakukan validasi buku ajar program linier yang telah di desain. Proses validasi melibatkan melibatkan 2 orang validator ahli yaitu ahli bidang nilai keislaman dan ahli bidang matematika. Validator tersebut adalah NZ (validator 1) dari program studi Pendidikan Agama Islam FTK UIN Suska Riau dan Bapak RZ (validator 2) dari program studi Pendidikan Matematika FKIP UIR. Rekapitulasi penilaian dari kedua validator terhadap buku ajar program linier dapat dilihat pada Tabel 5.

Tabel 5.

Rekapitulasi penilaian validasi buku ajar oleh validator

\begin{tabular}{llcc}
\hline \multicolumn{1}{c}{$\begin{array}{c}\text { Aspek } \\
\text { yang } \\
\text { dinilai }\end{array}$} & Butir Penilaian & $\begin{array}{c}\text { Vali- } \\
\text { dator } \\
\mathbf{1}\end{array}$ & $\begin{array}{c}\text { Vali- } \\
\text { dator } \\
\mathbf{2}\end{array}$ \\
\hline $\begin{array}{l}\text { Kelayakan } \\
\text { penyajian }\end{array}$ & $\begin{array}{l}\text { Sistematika } \\
\text { penyajian }\end{array}$ & 4 & 4 \\
\cline { 2 - 4 } & Keruntutan konsep & 3 & 4 \\
\hline \multirow{2}{*}{$\begin{array}{l}\text { Kelayakan } \\
\text { isi }\end{array}$} & $\begin{array}{l}\text { Kelengkapan } \\
\text { materi }\end{array}$ & 4 & 4 \\
\cline { 2 - 4 } & Keluasan materi & 3 & 4 \\
\cline { 2 - 4 } & Kedalaman materi & 3 & 4 \\
\hline
\end{tabular}

\begin{tabular}{|c|c|c|c|}
\hline & $\begin{array}{l}\text { Keakurasian } \\
\text { materi }\end{array}$ & 3 & 4 \\
\hline $\begin{array}{l}\text { Kesesuaian } \\
\text { dengan } \\
\text { prinsip } \\
\text { integrasi }\end{array}$ & $\begin{array}{l}\text { Kesesuaian } \\
\text { dengan prinsip } \\
\text { integrasi } \\
\text { keislaman }\end{array}$ & 4 & 4 \\
\hline $\begin{array}{l}\text { keislaman } \\
\text { dan } \\
\text { kemampuan } \\
\text { komunikasi } \\
\text { matematis }\end{array}$ & $\begin{array}{l}\text { Kesesuaian } \\
\text { dengan indikator } \\
\text { kemampuan } \\
\text { komunikasi } \\
\text { matematis }\end{array}$ & 3 & 4 \\
\hline \multirow{3}{*}{$\begin{array}{l}\text { Kelayakan } \\
\text { bahasa }\end{array}$} & $\begin{array}{l}\text { Ketepatan } \\
\text { penggunaan } \\
\text { kaidah bahasa }\end{array}$ & 4 & 3 \\
\hline & $\begin{array}{l}\text { Kemampuan } \\
\text { memotivasi dan } \\
\text { menyampaikan } \\
\text { pesan }\end{array}$ & 4 & 4 \\
\hline & Total Skor & 35 & 39 \\
\hline
\end{tabular}

Berdasarkan data yang disajikan pada tabel di atas diperoleh informasi bahwa kedua validator memberikan penilaian sebesar $(87,5 \%)$ dengan kriteria sangat valid dan $(97,5 \%)$ dengan kriteria sangat valid. Persentase gabungan dari kedua validator adalah sebesar $(92,5 \%)$ dengan kriteria sangat valid. Artinya, buku ajar yang dikembangkan di nilai sangat layak untuk digunakan tanpa revisi. Namun demikian, terdapat beberapa revisi kecil yang diberikan oleh validator dapat dilihat pada gambar berikut.

\begin{tabular}{|c|c|c|}
\hline Saran Validator 1 & $\begin{array}{c}\text { Saran } \\
\text { Validator 2 }\end{array}$ & Perbaikan yang dilakukan \\
\hline $\begin{array}{l}\text { 1. Lebih baik jumlah } \\
\text { uang yang } \\
\text { dihasilkan diganti } \\
\text { dengan jumlah } \\
\text { beras/padi yang } \\
\text { dihasilkan dalam } \\
\text { satuan ton atau } \\
\text { kuintal. } \\
\text { Kemudian diberi } \\
\text { harga jual } \\
\text { perkilogramnya. } \\
\text { 2. Hapus kata untuk } \\
\text { pada "petak } \\
\text { untuk sawah". } \\
\text { 3. Hapus kata } \\
\text { dengan pada } \\
\text { "diairi dengan air } \\
\text { hujan". }\end{array}$ & \begin{tabular}{|c} 
Perbaiki \\
dengan \\
mengganti \\
beberapa \\
kata yang \\
bisa \\
menimbulkan \\
ambigu, \\
seperti kata \\
"di beberapa \\
desa" \\
sebaiknya \\
diganti \\
dengan "dua \\
desa" saja.
\end{tabular} & $\begin{array}{l}\text { 1. Mengganti "... petak untuk sawah... " menjadi "... } \\
\text { petak sawah ..." } \\
\text { 2. Mengganti "...sawah yang diari dengan air hujan } \\
\text { 3. .." menjengadi "...sawah yang diari air hujan...." } \\
\text { tersebut menghasasilkan padi sawah-sawah berkualitas. } \\
\text { Setiap petak sawah yang diari dengan air hujan } \\
\text { dapat menghasilkan uang sebanyak Rp } \\
25.000 .000,00 \text { dan Rp } 50.000 .000,00 \text { untuk } \\
\text { setiap petak sawah yang memerlukan biaya } \\
\text { pengairan" menjadi "Semua sawah-sawah } \\
\text { tersebut menghasilkan padi yang berkualitas. } \\
\text { Setiap petak sawah menghasilkan beras siap jual } \\
\text { dengan harga jual } 10.000 \text { per kilogram } \\
\text { sebanyak } 2,5 \text { ton untuk sawah yang diari air } \\
\text { hujan dan } 5 \text { ton untuk sawah yang memerlukan } \\
\text { biaya pengairan". } \\
\text { 4. Mengganti "...di beberapa desa." menjadi "...di } \\
\text { dua desa." }\end{array}$ \\
\hline
\end{tabular}

Gambar 4. Perbaikan berdasarkan saran validator

\section{Tahap Implementation}

Pada tahapan ini, peneliti melakukan uji praktikalitas. Kegiatan awal yang peneliti lakukan pada tahapan ini adalah menerapkan penggunaan buku ajar yang telah melalui seluruh proses 


\section{JURNAL GANTANG. Maret 2021; VI(1): 47 - 60 \\ p-ISSN. 2503-0671 \\ e-ISSN. 2548-5547}

tahapan revisi berdasarkan hail validasi oleh validator yang dianggap ahli. Buku ajar ini diberikan kepada mahasiswa semester 5 kelas B Jurusan Pendidikan Matematika Fakultas Tarbiyah dan Keguruan Universitas Islam Negeri Sultan Syarif Kasim Riau yang berjumlah 27 orang.

Pada awalnya, subjek penelitian yang direncanakan berjumlah 33 orang. Namun ternyata dengan seiring perjalanan pembelajaran, terdapat 6 orang yang tidak secara penuh mengikuti seluruh tahapan proses pembelajaran, sehingga peneliti memutuskan keenam mahasiswa tersebut keluar dari subjek penelitian. Oleh karena itu, subjek penelitian dalam tahap implementation ini berjumlah 27 orang dengan rincian 24 mahasiswa perempuan dan 3 mahasiswa laki-laki.

Setelah peneliti menerima kembali angket yang telah diisi oleh seluruh mahasiswa, maka dilakukanlah perhitungan persentase dengan tiga jenis penggolongan. Pertama, perhitungan per-item pernyataan. Kedua, perhitungan per-variabel praktikalitas (indikator). Ketiga, perhitungan secara keseluruhan.

Adapun rekapitulasi perhitungan skor angket dapat dilihat pada Tabel 6 .

Tabel. 6.

Rekapitulasi perhitungan skor angket praktikalitas perindikator

\begin{tabular}{cccccc}
\hline $\begin{array}{c}\text { Indikator } \\
\text { Prak- } \\
\text { tikalitas }\end{array}$ & $\begin{array}{c}\text { Skor } \\
\text { Maks }\end{array}$ & $\begin{array}{c}\text { Skor } \\
\text { Min }\end{array}$ & $\begin{array}{c}\text { Rata- } \\
\text { rata }\end{array}$ & $\%$ & Ket. \\
\hline 1 & 5 & 2 & 4,43 & 88,5 & $\begin{array}{c}\text { Sangat } \\
\text { Praktis }\end{array}$ \\
\hline 2 & 5 & 2 & 4,25 & 84,9 & $\begin{array}{c}\text { Sangat } \\
\text { Praktis }\end{array}$ \\
\hline 3 & 5 & 3 & 4,23 & 84,6 & $\begin{array}{c}\text { Sangat } \\
\text { Praktis }\end{array}$ \\
\hline 4 & 5 & 3 & 4,13 & 82,6 & $\begin{array}{c}\text { Sangat } \\
\text { Praktis }\end{array}$ \\
\hline 5 & 5 & 3 & 4,41 & 88,1 & $\begin{array}{c}\text { Sangat } \\
\text { Praktis }\end{array}$ \\
\hline 6 & 5 & 3 & 4,15 & 83 & $\begin{array}{c}\text { Sangat } \\
\text { Praktis }\end{array}$ \\
\hline 7 & 5 & 3 & 4,15 & 83 & $\begin{array}{c}\text { Sangat } \\
\text { Praktis }\end{array}$ \\
\hline 8 & 5 & 2 & 3,76 & 75,2 & Praktis \\
\hline 9 & 5 & 2 & 4,11 & 82,2 & Sangat \\
\hline
\end{tabular}

\begin{tabular}{llllll}
\hline 10 & 5 & 3 & 4,69 & 93,7 & $\begin{array}{c}\text { Sangat } \\
\text { Praktis }\end{array}$ \\
\hline 11 & 5 & 3 & 4,59 & 91,9 & $\begin{array}{l}\text { Sangat } \\
\text { Praktis }\end{array}$ \\
\hline
\end{tabular}

Berdasarkan tabel di atas, dapat disimpulkan beberapa hal yaitu Pertama, untuk semua indikator praktikalitas, selalu ada mahasiswa yang memberikan penilaian 5 . Artinya, selalu ada mahasiswa yang menganggap bahwa aspek-aspek pada buku ajar ini sangat baik. Kedua, ada mahasiswa yang memberikan nilai 2 untuk empat indikator, yaitu indikator 1, 2, 8, dan 9. Artinya, ada mahasiswa yang menilai buku ajar program linier ini kurang baik dari aspek kesesuaian tampilan buku dalam menarik minat mahasiswa ketika menggunakannya (indikator 1), kurang baik dari aspek ketertarikan mahasiswa terhadap pembelajaran mata kuliah program linier dengan menggunakan buku ajar (indikator 2), keselarasan antara sistematika materi pada buku ajar dengan alokasi waktu di perguruan tinggi (indikator 8), dan keterdukungan latihan soal pada buku ajar dalam membantu mahasiswa untuk mengevaluasi pemahamannya terkait materi pembelajaran (indikator 9). Ketiga, dari 11 indikator, hanya 1 indikator yang dinilai oleh mahasiswa dengan penilaian dibawah 4 , yaitu pada indikator kedelapan (keselarasan antara sistematika materi pada buku ajar dengan alokasi waktu di perguruan tinggi). Sedangkan 10 pernyataan lainnya dinilai di atas 4 .

Adapun rekapitulasi perhitungan skor angket praktikalitas per-variabel praktikalitas dapat dilihat pada Tabel 7. Berdasarkan Tabel 7 dapat disimpulkan beberapa hal. Pertama, untuk semua variabel praktikalitas, selalu ada mahasiswa yang memberikan penilaian 5 . Artinya, selalu ada mahasiswa yang menganggap bahwa variabel praktikalitas pada buku ajar ini sangat baik. Kedua, ada mahasiswa yang memberikan nilai 2 untuk tiga variabel praktikalitas, yaitu variabel 1, 4, dan 5. Artinya, ada mahasiswa yang menilai buku ajar program linier ini kurang baik dari aspek minat mahasiswa dan tampilan buku (variabel 1), waktu (variabel 
4), dan evaluasi (variabel 5). Ketiga, dari 6 variabel praktikalitas, hanya 1 variabel yang dinilai oleh mahasiswa dengan penilaian dibawah 4, yaitu pada variabel 4 (waktu).

Tabel 7.

Rekapitulasi perhitungan skor angket praktikalitas per-variabel

\begin{tabular}{cccccc}
\hline $\begin{array}{c}\text { Variabel } \\
\text { Prak- } \\
\text { tikalitas }\end{array}$ & $\begin{array}{c}\text { Skor } \\
\text { Maks }\end{array}$ & $\begin{array}{c}\text { Skor } \\
\text { Min }\end{array}$ & $\begin{array}{c}\text { Rata- } \\
\text { rata }\end{array}$ & $\%$ & Ket. \\
\hline 1 & 5 & 2 & 4,37 & 87,3 & $\begin{array}{c}\text { Sangat } \\
\text { Praktis }\end{array}$ \\
\hline 2 & 5 & 3 & 4,2 & 84 & $\begin{array}{c}\text { Sangat } \\
\text { Praktis }\end{array}$ \\
\hline 3 & 5 & 3 & 4,23 & 84,7 & $\begin{array}{c}\text { Sangat } \\
\text { Praktis }\end{array}$ \\
\hline 4 & 5 & 2 & 3.76 & 75,2 & Praktis \\
\hline 5 & 5 & 2 & 4,11 & 82,2 & $\begin{array}{c}\text { Sangat } \\
\text { Praktis }\end{array}$ \\
\hline 6 & 5 & 3 & 4,65 & 93,1 & $\begin{array}{c}\text { Sangat } \\
\text { Praktis }\end{array}$ \\
\hline
\end{tabular}

Selanjutnya, rekapitulasi perhitungan skor angket praktikalitas secara keseluruhan dapat dilihat pada Tabel 8 berikut ini.

Tabel 8.

Rekapitulasi perhitungan skor angket praktikaalitas secara keseluruhan

\begin{tabular}{ccccc}
\hline $\begin{array}{c}\text { Skor } \\
\text { Maks }\end{array}$ & Skor Min & $\begin{array}{c}\text { Rata- } \\
\text { rata }\end{array}$ & $\%$ & Ket. \\
\hline 5 & 2 & 4,28 & 85,5 & $\begin{array}{c}\text { Sangat } \\
\text { Praktis }\end{array}$ \\
\hline
\end{tabular}

Berdasarkan tabel di atas, tampak bahwa persentase kepraktisan buku ajar program linier yang dikembangkan adalah sebesar $85,5 \%$. Persentase ini termasuk pada kategori kepraktisan dengan kriteria sangat praktis. Artinya, buku ajar ini sudah sangat praktis untuk digunakan oleh mahasiswa dalam pembelajaran pada mata kuliah program linier.

Setelah melakukan perhitungan skor dan menelaah rekapitulasi skor angket berdasarkan item pernyataan, indikator, variabel praktikalitas, dan secara keseluruhan, selanjutnya kesimpulan akhir terkait penggunaan buku ajar ini dapat dilihat pada Tabel 9 berikut.
Tabel 9.

Kesimpulan akhir mahasiswa terhadap buku ajar program linier yang dikembangkan

\begin{tabular}{cccccc}
\hline \multirow{2}{*}{$\begin{array}{c}\text { Kesim- } \\
\text { pulan } \\
\text { Akhir }\end{array}$} & $\begin{array}{c}\text { Ketertarikan } \\
\text { terhadap } \\
\text { Buku Ajar }\end{array}$ & $\begin{array}{c}\text { Keputusan Akhir } \\
\text { terhadap Kelayakan } \\
\text { Penggunaan Buku } \\
\text { Ajar }\end{array}$ \\
\cline { 2 - 6 } & Ya & Tidak & A & B & C \\
\hline Jumlah & 27 & 0 & 12 & 15 & 0 \\
\hline $\begin{array}{c}\text { Persen- } \\
\text { tase }\end{array}$ & 100 & 0 & 44,4 & 55,6 & 0 \\
\hline
\end{tabular}

Berdasarkan tabel di atas, tampak bahwa seluruh mahasiswa memutuskan bahwa mereka tertarik pada buku ajar program linier yang dikembangkan. Bahkan, 44,4\% diantara mereka (12 orang) menganggap bahwa buku ajar ini sangat baik untuk digunakan dalam pembelajaran mata kuliah program linier, tanpa perbaikan. Sisanya, sebanyak 15 orang $(55,6 \%)$ menganggap bahwa buku ajar program linier ini baik digunakan dengan terlebih dahulu melakukan perbaikan.

Sebelum melakukan revisi terhadap buku ajar yang dikembangkan, peneliti terlebih dahulu menginventarisir apa-apa saja yang harus diperbaiki. Hal ini dilakukan dengan cara mengumpulkan semua catatan berupa saran dan komentar yang ditulis oleh mahasiswa sebagai subjek praktikalitas. Adapun revisi yang harus dilakukan, yaitu:

1. Aspek desain dan tampilan:

a. Pada cover supaya lebih menarik, tampilan gambar matematika dipadukan dengan keislaman.

b. Desain gambar kurang cocok digunakan untuk bangku perkuliahan.

c. Gambar pada cover dan halaman 12 masih buram.

d. Warna pada nomor halaman terlalu gelap, sehingga nomor halaman tidak terlihat dengan jelas.

e. Pada materi metode grafik, dalam penentuan himpunan penyelesaian tidak begitu jelas, kalau bisa bedakan arsirannya agar himpunan penyelesaian terlihat jelas.

f. Tanda panah pada halaman 28 sebaiknya ditulis dengan warna yang berbeda dengan 


\section{JURNAL GANTANG. Maret 2021; VI(1): 47 - 60 \\ p-ISSN. 2503-0671 \\ e-ISSN. 2548-5547}

warna grafik, begitu juga dengan grafik berikutnya.

g. Gambar pada halaman 39 tidak jelas.

h. Tabel pada soal sebaiknya dirapikan lagi dengan memberi garis pada sisi-sisinya (sisi kanan dan kiri) dan berwarna agar menarik, seperti pada tabel 1.1 dan 2.1.

i. Bentuk umum persamaan sebaiknya dikotak, agar tersusun rapi.

2. Aspek penulisan

a. Pada kata pengantar, tulisannya seperti padat, lebih bagus dijarakkan lagi spasinya.

b. Pada halaman 7 contoh soal, lebih efektif kalau jawabannya langsung di bawah soal, jadi pembaca bisa lebih bisa memahaminya.

c. Pada halaman 34, spasinya dijarakkan lagi supaya lebih rapi.

d. Pada halaman 10, sebaiknya tidak dipisah dengan rangkuman, karena agar tidak membingungkan.

e. Perhatikan kesalahan penulisan, seperti pada halaman 12 dan 35 .

f. Untuk kata sumbu pada buku, misalnya "Titik potong dengan sumbu-x, maka..." garis penghubung antara sumbu dan $\mathrm{x}$ sebaiknya dihilangkan, karena bisa jadi mahasiswa akan mengira itu tanda negatif.

g. Keterangan gambar pada halaman 28 untuk koordinat titik, sebaiknya tanda koma diberi spasi, karena membuat pembaca ambigu.

h. Perhatikan penulisan huruf kapital.

i. Perbaiki spasi pada halaman 34 .

3. Aspek konten materi

a. Sebaiknya, setiap materi didukung dengan ayat Al-Qur'an dan hadits.

b. Perlu dibuat dalil tentang arti hadits/AlQur'an agar semakin bisa dihapal oleh orang yang membacanya.

c. Sebaiknya materi ini diperjelas dan diperinci lagi, seperti ketika SMA.

Selain merangkum saran dan komentar mahasiswa, peneliti juga melakukan perangkuman terhadap komentar positif terkait kelebihan buku ajar program linier yang dikembangkan. Pertama, tampilan dan keefektivan penggunaan buku ajar sudah bagus, karena selain belajar program linier, pembaca juga mengetahui tentang keislaman. Kedua, dari segi kemanfaatan, saya sangat bagus, karena bisa menambah ilmu tentang kisah-kisah yang terjadi pada masa Rasulullah sehingga membuat ketertarikan untuk mencari lebih banyak lagi tentang keislaman.

Ketiga, dari segi keefektivan, sangat efektif, penjelasannya tidak terlalu panjangdan bertele-tele, langsung ke intinya dan penjabarannya sangat jelas dan mudah dimengerti. Keempat, kualitas buku ini sangat bagus, dari kemanfaatan, tampilan, dan keefektivan penggunaannya sangat bagus dan tidak perlu diadakan perbaikan.

Kelima, buku ini sangat bermanfaat terutama bagi generasi milenial, karena anak muda zaman sekarang rata-rata ilmu tentang islam di bawah rata-rata. Keenam, buku program linier ini sangat bagus untuk dipublikasikan, karena dengan mengaitkan nilai-nilai islam, pemahaman mahasiswa bertambah. Bukan hanya belajar matematika saja, melainkan juga menambah atau mengingat kembali sejarah islam.

Ketujuh, dengan terbiasanya mahasiswa belajar dari buku yang diintegrasikan keislaman, setelah tamat dan menjadi guru, mudah baginya untuk membagikan ilmu matematika berbasis islam, tidak canggung lagi karena telah terbiasa dengan adanya contoh soal seperti sejarah islam, juga memudahkan mahasiswa mengingat materi yang telah dipelajarinya. Kedelapan, $95 \%$ buku program linier ini sangat bermanfaat untuk memahami pelajaran program linier, tampilannya pun sangat menarik dan gambar-gambar yang ada di dalamnya membuat saya tidak mudah bosan, sehingga buku ini cukup efektif untuk digunakan. Kesembilan, tampilan pada buku ini sangat menarik karena disertai dengan karakter yang manis dan gambar yang jelas dan sesuai dengan pembahasan yang dibahas. Warna yang digunakan sangat cantik dan menarik. 
Dengan memperhatikan semua saran dan komentar di atas, maka peneliti melakukan beberapa perbaikan terhadap buku ajar yang dikembangkan. Pertama, memperbaiki tampilan cover menjadi lebih menarik dengan cara memadukan gambar matematika dan keislaman. Gambar dan tulisan pada cover dibuat sedemikian hingga tidak terlihat pecah dan buram. Kedua, memperbaiki pengetikan tulisan pada kata pengantar agar tidak terlihat padat. Ketiga, memperbaiki semua gambar yang ada pada buku ajar menjadi lebih jelas dengan menggunakan warna yang tepat dan tingkat ketepatan yang akurat.

Keempat, mengubah nomor halaman dari warna putih menjadi hitam, agar terlihat lebih jelas. Kelima, memindahkan posisi jawaban dari contoh soal yang awalnya berada di bawah, setelah semua contoh soal ditampilkan, menjadi tepat langsung di bawah masing-masing contoh soal. Keenam, memperbaiki semua kesalahan penulisan.

Ketujuh, membedakan warna daerah himpunan penyelesaian dengan daerah lainnya pada metode grafik. Kedelapan, mengganti warna tanda panah yang menunjukkan persamaan garis yang ada pada grafik-grafik pada materi metode grafik, yang awalnya berwarna hitam menjadi warna hijau. Kesembilan, menghilangkan tanda " " pada kata "sumbu- $x$ ” dan "sumbu- $y$ ", agar tidak terjadi salah tafsir.

Kesepuluh, memperjelas tulisan koordinat titik pada halaman 28. Kesebelas, memperbaiki penulisan kapitalisasi. Kedua belas, memberi garis pada setiap baris dan kolom dalam tabel. Ketiga belas, bentuk umum persamaan dituliskan dalam sebuah kotak untuk memberi makna penekanan pentingnya tulisan yang terdapat pada kotak.

\section{Tahap Evaluation}

Setelah melakukan perbaikan buku ajar berdasarkan hasil uji praktikalitas, maka langkah selanjutnya yang harus peneliti lakukan adalah melakukan pengecekan akhir terhadap kesempurnaan buku ajar. Pengecekan akhir dilakukan dengan cara membandingkan perbaikan-perbaikan buku ajar yang telah peneliti lakukan dengan semua saran dan komentar dari validator dan mahasiswa sebagai subjek ujicoba praktikalitas. Pengecekan dilakukan dengan dua tahap, tahap pertama pembandingan perbaikan dengan saran dan komentar validator, dan tahap kedua pembandingan jawaban perbaikan dengan saran dan komentar mahasiswa.

Berdasarkan hasil pengecekan, semua saran dari validator pertama yang peneliti anggap ahli terhadap nilai keislaman telah peneliti lakukan dengan memperbaiki buku ajar sesuai apa yang telah disarankan. Namun, tidak begitu halnya dengan saran dari validator yang peneliti anggap ahli terkait materi program linier. Ada satu saran beliau yang tidak peneliti lakukan, yaitu menampilkan semua sumber kutipan tepat setelah pernyataan atau tepat di bawah gambar dan tabel. Hal ini tidak peneliti lakukan karena mempertimbangkan keefisienan buku ajar, selain semua sumber pada dasarnya telah peneliti cantumkan secara lengkap pada bagian daftar pustaka.

Selanjutnya, dari 21 poin saran yang diberikan mahasiswa, tidak semuanya peneliti lakukan. Terdapat lima saran yang tidak peneliti lakukan. Pertama, pada halaman 10, sebaiknya materi tidak dipisahkan dengan rangkuman. Hal ini tidak peneliti lakukan karena memang dari awal peneliti telah memutuskan bahwa setiap rangkuman pada tiap bab ditulis terpisah dengan halaman tersendiri. Selain itu, saran ini juga diberikan hanya oleh 1 orang mahasiswa. Artinya, saran ini bukanlah hal yang bisa dianggap urgen dan mempengaruhi pemahaman pembaca.

Kedua, sebaiknya, setiap materi didukung dengan ayat Al-Qur'an dan hadits. Hal ini tidak peneliti lakukan karena peneliti memang kesulitan untuk menemukan ayat Al-qur'an dan hadits yang secara jelas memiliki keterkaitan dengan materi pada buku ajar yang peneliti kembangkan. Oleh karena itu, peneliti lebih memilih mengaitkan materi pembelajaran dengan nilai keislaman dalam konteks sejarah (seperti perang dan kisah) serta aturan fiqih (seperti zakat dan warisan). 


\section{JURNAL GANTANG. Maret 2021; VI(1): 47 - 60 \\ p-ISSN. 2503-0671 \\ e-ISSN. 2548-5547}

Ketiga, dari segi tampilan, desain gambar kurang cocok digunakan untuk bangku perkuliahan. Desain gambar tetap peneliti biarkan sebagiamana adanya, kecuali gambar-gambar yang memang harus diperbaiki. Hal ini peneliti lakukan karena peneliti telah mempertimbangkan dengan seksama dan meminta saran dari yang berkompeten terkait gambar-gambar yang disajikan. Dan memang gambar-gambar tersebut masih relevan dengan dunia mahasiswa di perguruan tinggi. Selain itu, saran ini juga diberikan hanya oleh 1 orang mahasiswa. Artinya, saran ini bukanlah hal yang bisa dianggap urgen dan mempengaruhi pemahaman pembaca.

Keempat, perlu dibuat dalil tentang arti hadits/Al-Qur'an agar semakin bisa dihapal oleh orang yang membacanya. Hal ini tidak peneliti lakukan karena memang peneliti telah menuliskan dengan jelas semua arti ayat Al-Qur'an dan hadits yang disajikan dalam buku ajar yang dikembangkan.

Kelima, sebaiknya materi ini diperjelas dan diperinci lagi, seperti ketika SMA. Hal ini hanya pada sebagian materi saja yang peneliti lakukan, tidak pada semua materi, dikarenakan buku ajar ini direncanakan untuk pembelajaran mata kuliah program linier dengan rancangan 8 pertemuan atau setara setengah semester. Jika terlalu rinci, pasti akan memakan waktu pembelajaran yang lebih lama. Selain itu, buku ini ditujukan pada mahasiswa perguruan tinggi, bukan siswa SMA, dengan tuntutan kegiatan pembelajaran yang tidak sedetail di SMA.

\section{Pembahasan}

Berdasarkan hasil penelitian, maka terdapat beberapa hal yang perlu dilakukan pembahasan secara mendalam. Pertama, berdasarkan hasil perhitungan rata-rata skor angket praktikalitas, terdapat dua item pernyataan yang memiliki rata-rata skor kurang dari 4. Kedua item pernyataan tersebut adalah pernyataan nomor $9(79,3 \%)$ dengan kriteria praktis dan pernyataan nomor $20(65,2)$ dengan kriteria praktis.

Item pernyataan nomor 9 dengan bunyi pernyataan "belajar menggunakan buku ajar ini membuat saya menjadi lebih aktif di kelas" termasuk pada indikator "ketertarikan mahasiswa terhadap pembelajaran program linier dengan menggunakan buku ajar". Indikator ini termasuk pada variabel praktikalitas "minat mahasiswa dan tampilan buku". Rendahnya persentase skor pada item pernyataan nomor 9 tidak mengakibatkan kepada rendahnya indikator dan variabel praktikalitasnya. Hal ini karena untuk indikator yang bersesuaian, terdapat 2 item pernyataan lainnya yang memiliki rata-rata yang tinggi.

Selain itu, setelah dikaitkan dengan saran dan komentar mahasiswa, pada dasarnya mereka sangat tertarik menggunakan buku ajar program linier yang dikembangkan dalam pembelajaran, karena banyak pengetahuan keislaman yang telah mereka peroleh. Namun memang dengan rinci dan banyaknya sisipan pengetahuan baru terkait keislaman yang ada pada buku ajar membuat mereka fokus dan berkonsentrasi untuk membaca, memahami, dan mengerjakan soal-soal yang ada pada buku ajar. Hal ini menyebabkan turunnya intensitas mereka dalam berkomunikasi di kelas, dengan kata lain terjadinya pengurangan tingkat percakapan/diskusi selama proses pembelajaran berlangsung.

Hal ini bisa berdampak positif dan negatif secara bersamaan. Positifnya adalah kegiatan pembelajaran di kelas semakin tenang dan kondusif dalam penyampaian ilmu serta kemandirian belajar mahasiswa semakin terlatih. Menurut Misdalina dkk. (2017) kemandirian belajar berpengaruh positif terhadap hasil belajar. Namun negatifnya adalah konsep kooperatif dan kerja sama yang senantiasa selalu ditanamkan di era pembelajaran berbasis konstruktuvisme akan semakin sulit terjadi.

Selanjutnya, item pernyataan nomor 20 yang berbunyi "saya tidak membutuhkan waktu tambahan di luar alokasi waktu yang telah disediakan ketika belajar menggunakan buku ajar ini" termasuk pada indikator "keselarasan antara sistematika materi pada buku ajar dengan alokasi waktu di perguruan tinggi" dengan variabel praktikalitas "waktu". Hanya terdapat 2 pernyataan pada indikator ini, yaitu item 
pernyataan nomor 19 dan 20. Oleh karena itu, rendahnya persentase skor tersebut mempengaruhi persentase skor angket praktikalitas per-indikator dan variabel praktikalitas yang bersesuaian.

Setelah dikaitkan dengan saran dan komentar (baik itu komentar kelebihan maupun kekurangan buku ajar), bisa disimpulkan bahwa dengan semakin rincinya buku ajar, menyebabkan jumlah halaman yang dibaca semakin bertambah, sementara pada bacaan dalam buku ajar yang dikembangkan ini memuat banyak hal baru yang pada dasarnya jarang tersampaikan seperti sejarah perang dan kisah keislaman, serta fiqih islam. Hal ini pasti akan menyita waktu yang lebih banyak ketika belajar menggunakan buku ajar ini dibandingkan dengan menggunakan buku-buku lainnya. Apalagi jika memang mahasiswa tertarik dengan info-info seperti ini. Tentu akan membuat mereka membaca dengan lebih seksama dan lama. Akibatnya, durasi alokasi waktu yang diberikan akan cenderung tidak memenuhi.

Kekonsistenan penggunaan alokasi waktu berdasarkan apa yang telah direncanakan inilah yang menjadi salah satu kelemahan pada penelitian ini. Padahal menurut Sari (2019) ada pengaruh positif antara durasi belajar dengan hasil belajar matematika yang diperoleh siswa. Di satu sisi peneliti senang melihat antusias mahasiswa dalam membaca dengan seksama buku ajar dan mengerjakan soal-soal yang diberikan, tapi disisi lain, dengan semakin seksama dan hanyutnya mereka dalam membaca, maka akan semakin memakan waktu pembelajaran, apalagi jika tidak diingatkan. Bahkan jika dibiarkan, mereka malah cenderung membicarakan konsep keislaman dibandingkan materi program linier itu sendiri.

\section{Kesimpulan}

Berdasarkan hasil penelitian dan pembahasan, maka diperoleh dua kesimpulan. Pertama, buku ajar program linier terintegrasi keislaman berbasis kemampuan komunikasi matematis berada pada tingkat validitas sangat valid. Adapun numerik nilai validitas yaitu sebesar 92,5\%. Kedua, buku ajar program linier terintegrasi keislaman berbasis kemampuan komunikasi matematis berada pada tingkat praktikalitas sangat praktis. Adapun numerik nilai validitas yaitu sebesar $85,5 \%$.

\section{Ucapan Terimakasih}

Artikel ini merupakan publikasi hasil penelitian dengan klaster peningkatan kualitas LPPM Universitas Islam Negeri Sultan Syarif Kasim Riau. Oleh karena itu, penulis mengucapkan terimakasih kepada LPPM Universitas Islam Negeri Sultan Syarif Kasim Riau. atas dukungan pendanaannya demi kesuksesan penelitian ini.

\section{Referensi}

Akbar, S. (2013). Instrumen perangkat pembelajaran. Bandung: PT Remaja Rosdakarya.

Asmayanti, A., Cahyani, I., \& Idris, N. S. (2020). Model ADDIE untuk pengembangan bahan ajar menulis teks eksplanasi berbasis pengalaman. Seminar Internasional Riksa Bahasa XIV, 259-267. Bandung: Universitas Pendidikan Indonesia.

Astuti, A., \& Leonard, L. (2015). Peran kemampuan komunikasi matematika terhadap prestasi belajar matematika siswa. Formatif: Jurnal Ilmiah Pendidikan MIPA, 2(2).

Febrianto, R., \& Puspitaningsih, F. (2020). Pengembangan buku ajar evaluasi pembelajaran. Education Journal: Journal Educational Research and Development, 4(1), 1-18.

Fitriyani, D., \& Kania, N. (2019). Integrasi nilainilai keislaman dalam pembelajaran matematika. Prosiding Seminar Nasional Pendidikan, 1, 346-352. Banten: FKIP UNMA. Diambil dari https://prosiding.unma.ac.id/index.php/se mnasfkip/article/view/49

Hodiyanto, H. (2017). Kemampuan komunikasi matematis dalam pembelajaran matematika. AdMathEdu, 7(1), 9-18.

Khikmiyah, F., \& Midjan, M. (2017). Pengembangan buku ajar literasi matematika untuk pembelajaran di SMP. Jurnal Silogisme: Kajian Ilmu Matematika 
JURNAL GANTANG. Maret 2021; VI(1): 47 - 60

p-ISSN. 2503-0671

e-ISSN. 2548-5547

dan Pembelajarannya, 1(2), 15-26.

Kurniati, A. (2015). Mengenalkan matematika terintegrasi islam kepada anak sejak usia dini. Suska Journal of Mathematics Education, 1(1),1-8. https://doi.org/10.24014/sjme.v1i1.1326

Mahardhika, G. P. (2015). Digital game based learning dengan model ADDIE untuk pembelajaran doa sehari-hari. Teknoin, 22(2), $1-8$.

https://doi.org/10.20885/.v22i2.3700

Menteri Pendidikan Nasional. (2003). UU RI Nomor 20 Tahun 2003 tentang sistem pendidikan nasional. Kementrian Pendidikan Nasional.

Misdalina, M., Ningsih, Y. L., \& Marhamah, M. (2017). Pengaruh kemandirian belajar terhadap hasil belajar mahasiswa. Jurnal Dosen Universitas PGRI Palembang, 858861. Palembang: Pengurus besar PGRI.

Nartani, C. I., Hidayat, R. A., \& Sumiyati, Y. (2015). Communication in mathematics contextual. International Journal of Innovation and Research in Educational Sciences, 2(4), 284-287.

Riduwan. (2010). Dasar-dasar statistika. Bandung: Alfabeta.

Riduwan, \& Sunarto. (2013). Pengantar statistika untuk penelitian pendidikan, sosial, ekonomi, komunikasi, dan bisnis. Bandung: Alfabeta.

Sari, B. T. W. (2019). Pengaruh durasi belajar terhadap hasil belajar matematika siswa kelas 5 ledok 006 salatiga. Jurnal Review Pendidikan dan Pengajaran, 2(1), 139144.

Sudijono, A. (2008). Pengantar statistik pendidikan. Jakarta: Raja Grafindo.

Supriadi, N. (2015). Mengembangkan kemampuan koneksi matematis melalui buku ajar elektronik interaktif (baei) yang terintegrasi nilai-nilai keislaman. $A l$ Jabar: Jurnal Pendidikan Matematika, 6(1),63-74.

https://doi.org/10.24042/ajpm.v6i1.51

Wichelt, L., \& Kearney. (2009). Communication: A vital skill of mathematics. University of Nebraska Lincoln. 